\title{
Determination of lethal dose (LD50) of Exotoxin A from Pseudomonasaeruginosa26A in mice histopathology
}

\author{
Essam F, Al-Jumaily ${ }^{1}$ Bushra H. Saleh ${ }^{2}$ andShalal M. Hussain ${ }^{3}$ \\ ${ }^{I}$ Biotechnology Depart./Institute of Genetic Engineering and Biotechnology for postgraduate studies, Baghdad \\ University, IRAQ. \\ ${ }^{2}$ Medical Microbiology Department, Medical College, Al-Nahrain University, Baghdad, IRAQ. \\ ${ }^{3}$ Iraqi Center for Cancer and Medical Genetics Research, Al-Mustanseria University, IRAQ.
}

\begin{abstract}
This study was conducted for investigating to determination of lethal dose (LD50) of purified toxin A produced frompseudomonas aeruginosa $(26$ A) strain in mice histopathology.

LD50 of purified toxin A produced from pseudomonas aeruginosa26A strainwas detected after injection different concentration of purified toxin $A(0.05,0.1,0.2,0.25,1,2$ and 4$) \mu \mathrm{g} / \mathrm{ml}$ in mice and lethality were recorded for five days which reveal that LD50 of purified toxin was $1 \mu \mathrm{g} / \mathrm{ml}$. On the other hand histopathological examination of liver, spleen and kidney in mice injected with high doses reveal significant histopatholgical degeneration .

Key words: lethal dose, Exotoxin A, Pseudomonas aeruginosa, mice histopathology
\end{abstract}

\section{Introduction}

Pseudomonas aeruginosa is the leading etiology of gram negative bacteria at most medical centers and its always listed as one of the top three most frequent Gram-negative pathogens that linked to the worst visual diseases [1] .

P.aeruginosa is an opportunistic human pathogen. It is opportunistic because its seldom infects healthy individuals. Instead, it often colonizes immunocompromised patients, like those with cystic fibrosis, cancer, or AIDS [2]. Itsa potent pathogen that firstly attacks up two thirds of the critically ill hospitalized patients and cause $40-60 \%$ mortality rate [3]. It also exhibits intrinsic resistance to a lot of different types of chemotherapeutic agents and antibiotics, making it a very hard pathogen to eliminate [4].

Exotoxin A (ETA) is considered as the most toxic virulence factor secreted by $P$. aeruginosa. The toxin was first discovered and purified by Liu who reported that $P$. aeruginosa PA103, a protease-deficient strain, produces more toxin than $P$. aeruginosa strains which actively produce proteases [5].Exotoxin A appears to mediate both local and systemic disease processes caused by P.aeruginosa. It has necrotizing activity at the site of bacterial colonization and is thereby thought to contribute to the colonization process [6].

ETA is a heat-labile, single polypeptide chain consist of 613 amino-acid and four disulfide linkages with a molecular weight of $66 \mathrm{kDa}$. X ray crystallographystudies and deletion mutation analysis of ETA revealed the overall tertiary structure of the molecule which consists of three functional domains in order to be toxic, namely binding to the receptor on the cell membrane, translocation across the membrane, and ADP ribosylation activities $[7,8]$.

\subsection{Preparation of exotoxin $A$}

\section{Materials and Methods}

A toxigenic strain of $P$. aeruginosa(PA 26A) was used for exotoxin A preparation. Exotoxin A was partially purified and purified according to the method described by Salehet al.[9].

Groups of Swiss albino BALB/c mice, which were obtained from theICCMGR, were used in this study .mice were kept in cages in animal house with $23-25^{\circ} \mathrm{C}$ temperature and were fed with suitable quantity of water and complete diet.

\subsection{Determination of exotoxin A toxicity $A$ in mice}

Groups consists of 20 mice (females). Their ages ranged between (8-12) weeks and weighting (20-25) gram. They were divided into (4) groups and the last one was left as control. Each group was kept in a separate plastic cage. Three toxin extract from three different protease negative strains were given in which each group received one toxin. Mice in each group were treated with $(0.5) \mathrm{ml}$ of stage I toxin A that administrated intraperitoneally, while each mice in the control group administrated (0.5)ml of sterile PBS. The animals were observed for five days, and record the result of death. 


\subsection{Experimental burn infection [10]}

Groups consists of 21 mice ( females). Their ages ranged between (8-12) weeks and weighting (20-25) gram. They were divided into (3) groups. Each group was kept in a separate plastic cage and given food and water .Anaesthised mice were shaved back involving approximately $30 \%$ of the total body surface, then they were given a 30 -s burn with hot metal .

Group one Immediately after burning approximately $1 \times 10^{8}$ live organisms in $0.5 \mathrm{ml}$ of physiological saline (PBS) were injected subcutaneously in the burned area in the first group .

Group Two : After burning received $1 \times 10^{8}$ livebacterial cell then animal received $0.1 \mathrm{ml}$ of gentamicin solution intraperitoneally and a similar volume subcutaneously in the infected burned area, the total dose per kilogram bodyweight being $100 \mathrm{mg}$.

Group Three : burned but uninfected control animals received $0.5 \mathrm{ml}$ of sterile PS instead of bacterial suspension. The animal were observed for 5 day and the result were recorded daily.

\subsection{Determination of LD50 of toxin A}

The LD50 of toxin was determined according to the Reed and Muench [11], 40 mice were divided in to 8 group ,the last one used as control, different concentration of purified toxin were prepared $(0,05,0.1,0.2$ $, 0.25,1.0,2.0$ and $4.0 \mu \mathrm{g} / \mathrm{ml}$ by diluted the concentrate toxin with $0.01 \mathrm{M}$ Tris- $\mathrm{OH}$. Each group was assigned to one of dilution, then $0.5 \mathrm{ml}$ of toxin was injected intraperitoneally in mice, while in control group each mice were received $0.5 \mathrm{ml}$ of $0.01 \mathrm{M}$ Tris- $\mathrm{OH}$. Mice were observed daily for 5 day, then LD50 were determined and calculated.

\section{Results And Discussion}

For determination the LD50 of purified toxin A in mice . 40 mice were divided in to 8 group, the last was used as control. Different concentration of purified toxin A $0,05,0.1,0.2,0.25,1.0,2.0$ and $4.0 \mu \mathrm{g} / \mathrm{ml}$ were used . Each group was assigned to one of dilution that $0.1 \mathrm{ml}$ of purified toxin A was injected intraperitoneallyin mice, while control group were received $0.1 \mathrm{ml}$ of $0.01 \mathrm{M}$ Tris- $\mathrm{OH}$. Mice were observed daily for mortalityfor 5 days. The LD50 of purified toxin A was expressed as micrograms of protein per $20 \mathrm{~g}$ of body weight. Results of injection of purified toxin A have shown that the LD50 of purified toxin A that give more than $50 \%$ lethality of mice was recorded and calculated to be $1 \mu \mathrm{g} / \mathrm{ml}$ in to laboratory mice .

\subsection{Histopathological examinationLiver}

Histopathological examination of liver in mice injected with higher doses of purified toxin A 1.5 and 2 $\mu \mathrm{g} / \mathrm{ml}$ reveal that there is congestion of central vein, enlargement and vaculation of hepatocyte which lead to stenosis of sinusoid with infilteration of inflamatory cells as shown in Figures(1 and 2). In higher doses 3 and $4 \mu \mathrm{g} / \mathrm{ml}$ there is area of necrotizing hepatocyte with absence of sinusoid and presence of mitotic figure. Also extensive mononuclear cell infilterationand presence of apoptotic hepatocyte is also seen in some part of liver in higher doses as shown in figure (3). Liver in control group injected with $0.1 \mathrm{ml}$ of $0.01 \mathrm{MTris}-\mathrm{OH}$ intraperitoneally show normal tissue section as seen in Figure(4).

\section{Spleen and kidney}

Histopathological examination of spleen in mice injected with higher doses of toxin 1.5 and $2 \mu \mathrm{g} / \mathrm{ml}$ in mice, reveal that there is depletion of lymphoid follicles in spleen with presence of large number megakaryocyte as seen in figure(5). In higher doses 3 and 4 there is depletion of lymphoid follicles and precipitation of amyloid like substances as shown in figure (6) . spleen in control group injected with $0.1 \mathrm{ml}$ of $0.01 \mathrm{M}$ Tris- $\mathrm{OH}$ intraperitoneally revealed normal tissue structure as shown in figure (7).

In kidney, at doses 1.5 and $2 \mu \mathrm{g} / \mathrm{ml}$ there is necrotic area and infilteration of inflammatory cells in the brankeyma as seen in figure (8). In higher doses 3 and 4 there is atrophy of glomululartafts, sloughing and destruction of epithelial lining urinary tubules and enlargement of poman space lead to stenosis of lumen also infilteration of inflamatory cells as shown in figure (9). Alsothere is formation of hyaline cast in some part of kidney in higher doses as see in figure (10). kidney in control group injected with $0.1 \mathrm{ml}$ of $0.01 \mathrm{M}$ Tris-OH intraperitoneally revealed normal tissue structure as shown in figure (11).

Results of injection of purified toxin A in mice have shown that the LD50 of purified toxin A that give more than $50 \%$ lethality of mice was calculated to be $1 \mu \mathrm{g} / \mathrm{ml}$. Tzonget al [12] reported that subcutaneous administration of truncated part of PE(576-613) at dose of $250 \mu \mathrm{g}$ was still nontoxic to 5- and 9-week-old ICR mice, while the native PE was lethal at a dose of $0.5-1 \mu \mathrm{g}$ respectively. Also[13,14] noted that native PE inhibits protein synthesis both in vivo and in vitro by adenosine diphosphate (ADP)-ribosyltransferase activity on elongation factor 2 and was lethal at a dose of $1 \mu \mathrm{g}$ when injected in to laboratory mice. While [15,8 ] noted that the purified toxin had a mouse median lethal dose of $0.1-0.15 \mu \mathrm{g} / 22 \mathrm{~g}$ mouse when injected intraperitoneally, also Michael and Barbara [16] reported that LD50 of toxin A was $0.2 \mu \mathrm{g} / \mathrm{ml}$ when 
injected intrapertoneally to mice. Ali et al[10] show that purified toxin had a mouse median lethal dose of 300 $\mathrm{ng} / 22 \mathrm{~g}$ mouse when injected intraperitoneally.

Histopathological examination of liver in mice injected with higher doses of PE 1.5 and $2 \mu \mathrm{g} / \mathrm{ml}$ reveal that toxin A exerted a marked effect on the liver characterize by the presence of vaculated hepatocyte with infilteration of inflamatory cells. [17, 18]study that the histopathology and serum enzyme levels in mice inoculated with Pseudomonas aeruginosa exotoxin A intravenously in which toxin A exert their effect on the liver. The microscopic lesions caused in the liver by a single injection of two $50 \%$ lethal doses (LD50) of toxin $2.3 \mu \mathrm{g}$ were characterized by cellular swelling, and fatty change within 4-8 hrs and near total hepatocellular necrosis at $48 \mathrm{hr}$. Hepatic necrosis was accompanied by a parallel rise in serum levels of aspartate and alanine aminotransferases and alkaline phosphatase. A single injection of 5 dose of (LD50) elicited similar but somewhat more rapid degeneration. Also [19] noted that administration of the higher dose of PEA cause lethality in mice within $16 \mathrm{hrs}$. The liver characterized by hepatocyte degeneration, also release of liverenzymes was preceded by the appearance of cytosolic oligonucleosome-boundDNA within the liver that was significantly enhanced $6.5 \mathrm{hrs}$ after PEA administration. Internucleosomal DNA fragmentationas a measure of programmed cell death was also demonstratedon an agarose gel.

Histopathological examination of liver in mice injected with higher doses of PE 3 and $4 \mu \mathrm{g} / \mathrm{ml}$ reveal degeneration of liver characterize by the presence of vacuolated hepatocyte and extensive infiltration of inflammatory cells, in addition to the presence of apoptotic cells. The prevalence of apoptotic cell death in PEAinduced liver injury could be explained by mechanisms of sensitization toward TNF. These include significant inhibition of protein synthesis in the case of PEA-induced liver damage.- Furthermore, cytotoxic lymphocytes may contribute to the apoptotic morphology in PEA-induced liver injury, by producing perforin[20, 21].

Shafikhaniet al .[22] reveal that transmission electron micrographs of mouse livers excised $12 \mathrm{~h}$ following injection of higher doses of PEA show that the dying cells were hepatocytes. They diedby apoptosis and necrosis whereasneither apoptosis nor necrosis was seen in livers of saline-treatedmice. Necrotic liver areas contained infiltrated polymorphonuclear neutrophils . Jens et al.[19] noted that pretreatment mice with $\mathrm{Cl}_{2} \mathrm{MBP}$ liposomes strongly attenuated liver injury induced by PEA. This pretreatment restricted liver damage to some areas of focal confluent necrosis, which were not sufficient to cause significant release of transaminases while the livers of PEA-treated mice contained foci of confluent necrosis and cells with apoptotic morphology.

Results of injection of purified toxin A in mice have shown that the LD50 of purified toxin A that give more than $50 \%$ lethality of mice was calculated to be (1) $\mu \mathrm{g} / \mathrm{ml}$. Tzonget al [12]reported that subcutaneous administration of truncated part of PE(576-613) at dose of $250 \mu \mathrm{g}$ was still nontoxic to 5- and 9-week-old ICR mice, while the native PE was lethal at a dose of $(0.5-1) \mu \mathrm{g}$ respectively. Also $[13,14]$ noted that native PE inhibits protein synthesis both in vivo and in vitro by adenosine diphosphate (ADP)-ribosyltransferase activity

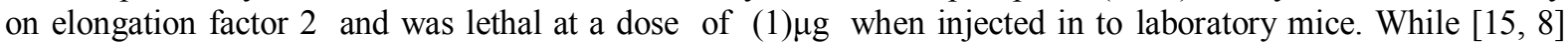
noted that the purified toxin had a mouse median lethal dose of $0.1-0.15 \mu \mathrm{g} / 22 \mathrm{~g}$ mouse when injected intraperitoneally, also [16] reported that LD50 of toxin A was $0.2 \mu \mathrm{g} / \mathrm{ml}$ when injected intrapertoneally to mice. Ali et al .[10] show that purified toxin had a mouse median lethal dose of $300 \mathrm{ng} / 22 \mathrm{~g}$ mouse when injected intraperitoneally.

\section{References}

[1] M.R. Fogle. (2012).The role of exotoxin A in the pathogensis of pseudomonas aeruginosa burn wound infection .Texas Tech university Electronic Teses and Dissertations. Taxes Library Web: www.handle.net/2346/17059.

[2] E.H. Karimi;P. Pourkashanifand H. Chanatpishe. Frequency of pseudomonasaeruginosa serotypes in burn wound infection and their resistance to antibiotics. Burns.28, 2002. $340-348$.

[3] P.V. Applgren;K. Bjornhagen; C.E. Bragderyd and U. Ransjo.A prospective study of infections in burn patients.Burn.28 ,2002. $34-$ 46.

[4] U.S.AltoParlak; M.N. Erol; F.C. Akcayand A. Kadanali.The time - related changes of anti Microbiol resistance patterns and predominant bacterial profiles of burn wounds and body flora of burned patients. Burns. 30. 2004. $660-664$.

[5] S. Guadarrama;E.D. Pulcini; S.C. Broadaway and B.H. Pyle. Pseudomonas aeruginosa growth and production of exotoxin A in static and modeled microgravity environment Gravit\& space. Biol. 18 (2), 2005. 85 - 86.

[6] M. Pollack. The role of exotoxin., A in pseudomonas disease and immunity. J. infect. Dis. 5 , $1983.979-984$.

[7] F. Danielle, F. Environmental parameters of growth of Microbiology Lab report 2, medical publishing division, New York, 2007.

[8] P.Y. Susan.; L.T. Patricia and M. Rod.Structure function analysis of the catalytic domain of exotoxin A from pseudomonas aeruginosa. J. Biochem. 385. 2005. $667-675$.

[9] B.H. Saleh,E.F.Al-Jumaily and S.M. Hussain. Production and Purification of Exotoxin Aextracted from social strains of Pseudomonas aeruginosain Iraq.Trends in Biotechnology.1. 2012. 15-23.

[10] M. Ali; K. Jamshid;M. Davood; J. Aziz ; A. Masoud and K. Nazanin. Active immunization using exotoxin A confers protection against pseudomonas aeruginosinfection in a mouse burn model BMC. Micrbiol. . 2009. 1-10.

[11] L. Reed L and H.A. Muench .Simple method for estimating 50\% endpoint.Am J Hyg,25. 1938. 493-497.

[12] Y.C.Tzong ;P.L.Chia; C.L.Chien and F.H. Cho. A non toxic pseudomonas exotoxin A induce active immunity and passive protective antibody against pseudomonas exotoxin A intoxication . J. Biomed. Sci. 6. 1999. 357-363.

[13] S. Armstrong and A.R. Merrill.Application of fluorometric assay for characterization of catalytic competency of domain III fragment of pseudomonasaeruginosa exotoxin A. Biochm. 292. 2001. $26-33$. 
[14] M.D. Robert and S. Debell . Production of exotoxin A by pseudomonas aeruginosa in a chemically defined medium. Infect. Immun. 24. 1. 1979. 132-138.

[15] E.O. Dennis ; C.S. Jerald and H.I. Barbara. Toxin A Deficient mutants of pseudomonas aeruginosa PA103: isolation and characterization. Infect. Immun. 28, 3. 1980. $899-908$.

[16] L.V. Michael and H.I. Barbara.Comparative toxicities of diphtheria toxin and pseudomonasaeruginosa exotoxin A: Evidence for different cell receptors. J. Gen. Microbiol 108. 1978. 333-334

[17] H. Papadaki; G. Dimitracopoulos ; D. Bonicos and E.D. Anastassion. Histological alteration in mice induced by pseudomonas exotoxin A. 5.1. 1990. 7-18

[18] R. Olgerts; A. Frank and H. Shackel ford. PseudomonasareuginosaExotoxin in mice histopathology and serum enzyme changes. J. Med. Microbiol. 3. 1976. $253-255$.

[19] S. Jens; A. Sabine; B. Renate; L. Michael. and T. Gisa.A cute hepatotoxicity of pseudomonas aeruginosa exotoxin A in mice depend on T cells and TNF. J. Immun. : 161. 1998. $5745-5754$.

[20] C.ChienChao,H. Hans; L. Hsiao; C. Tung - Chung and H. Ten-Te.Pseudomonasaeruginosa exotoxin A induced Hepatotoxicity: an animal model in rats, J. vet. Med. Sci, 71. 1. 2002.1-8.

[21] V. Jendrossek; H. Grassme and I. Muller.Pseudomonas aeruginosainduces apoptosis involve mitochondria and stress activated protein kinases. Infect. Immun. 69. 2001. 2675-2683.

[22] S.H. Shafikhani; C. Morales and J. Engel. ThePseudomonas aeruginosatype III secreted toxin Exo T is necessary and sufficient to induce apoptosis in epithelial cells. Cell.Microbiol.10. 2008. $994-1007$.

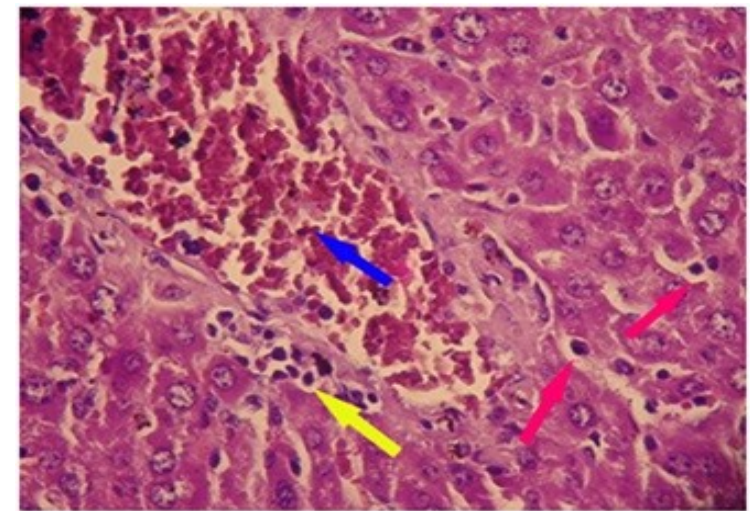

Figure (1) :Histopathological section of liver in mice injected with $0.1 \mathrm{ml}$ of purified toxin at concentration $1.5 \mu \mathrm{g} / \mathrm{ml}$ showed congestion of blood vessel (blue arrow) with infilteration of inflamatory cell( yellow arrow) and presence of vaculated hepatocyte(red arrow).(x400).H \& E.

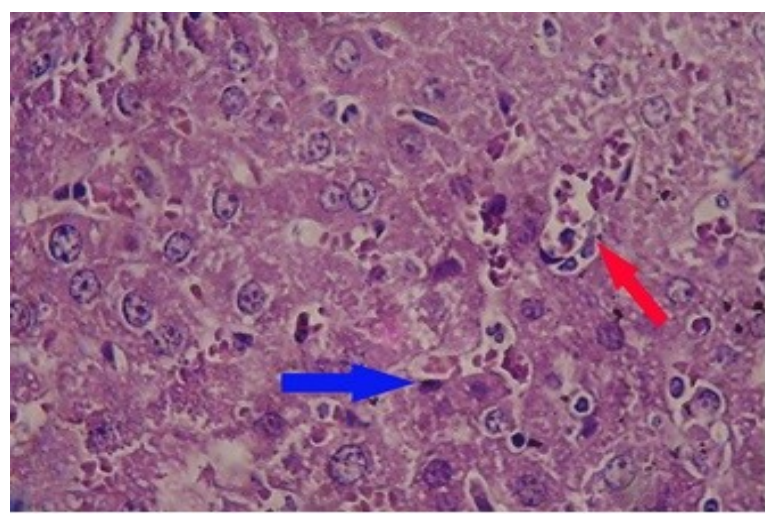

Figure (3) :Histopathological section of liver in mice injected with $0.1 \mathrm{ml}$ of purified toxin at concentration $4 \mu \mathrm{g} / \mathrm{ml}$ showed congestion of blood vessel( red arrow) and presence of apoptotic hepatocyte(blue arrow) .(x400).H \& E.

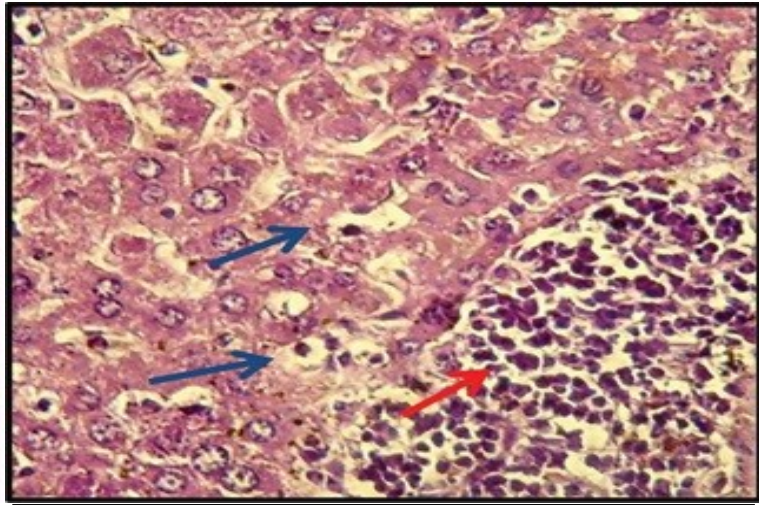

Figure (2):Histopathological section of liver in mice injected with $0.1 \mathrm{ml}$ of purified toxin at concentration $2 \mu \mathrm{g} / \mathrm{ml}$ showed presence of vaculated hepatocyte (blue arrow) in addition to extensive mononuclear cell infilteration ( red arrow) .( x400) .H \& E.

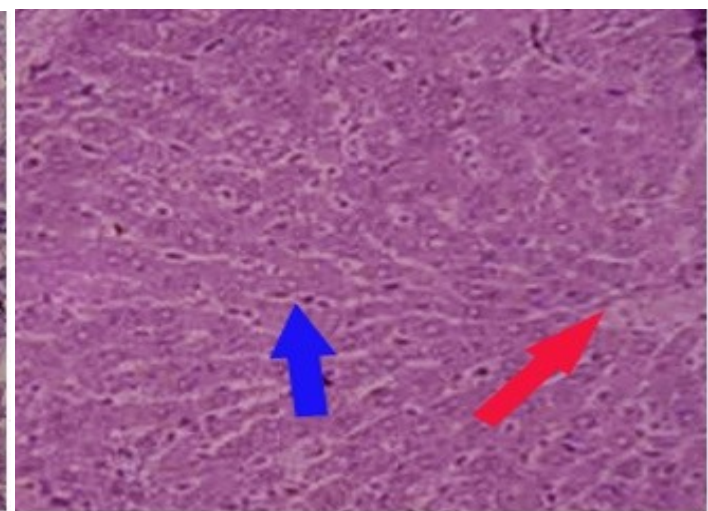

Figure (4): Histopathological section of liver in contro group injected with $0.1 \mathrm{ml}$ of PBS showed normal tissue section contain central vein (red arrow) and hepatic cord( blue arrow) .(x100).H \&E. 


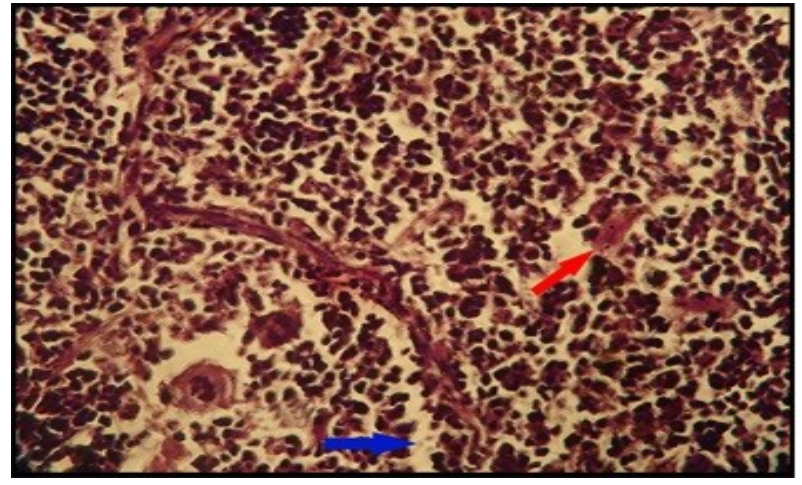

Figure (5) :Histopathological section of spleen in mice injected with $0.1 \mathrm{ml}$ of purified toxin at concentration $2 \mu \mathrm{g} / \mathrm{ml}$ showed depletion of lymphoid follicule(blue arrow) and presence of megakaryocyte ( red arrow). $(\mathrm{x} 400) . \mathrm{H} \&$ E.

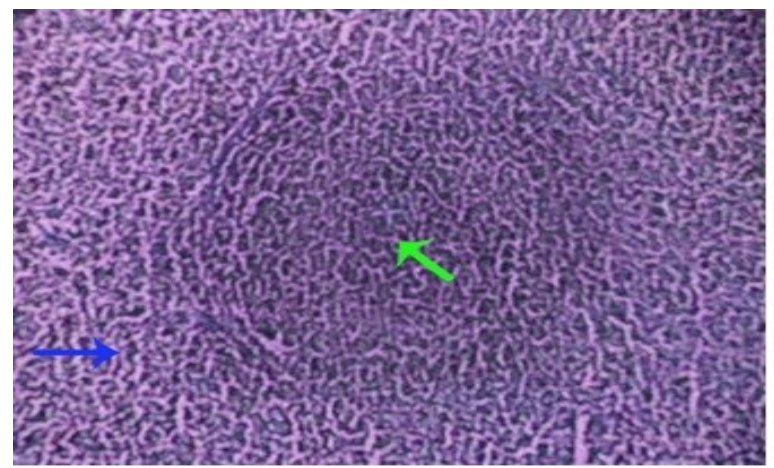

Figure (7): Histopathological section of spleen in control group injected with $0.1 \mathrm{ml}$ of Tris-oH showed normal tissue section consistof white pulp (green arrow) and red pulp ( blue arrow) .(x 100).

$\mathbf{H} \& \mathbf{E}$

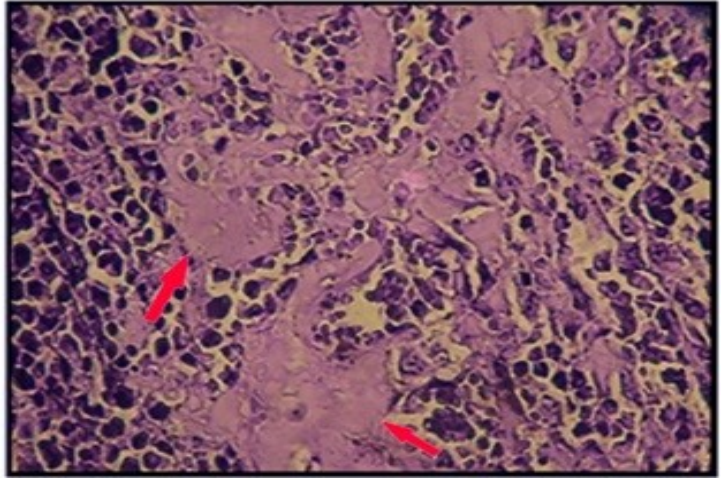

Figure (6) :Histopathological section of spleen in mice injected with $0.1 \mathrm{ml}$ of purified toxin at concentration $3 \mu \mathrm{g} / \mathrm{ml}$ showed precipitation of amyloid like substances ( red arrow).(x 400).H \&E.

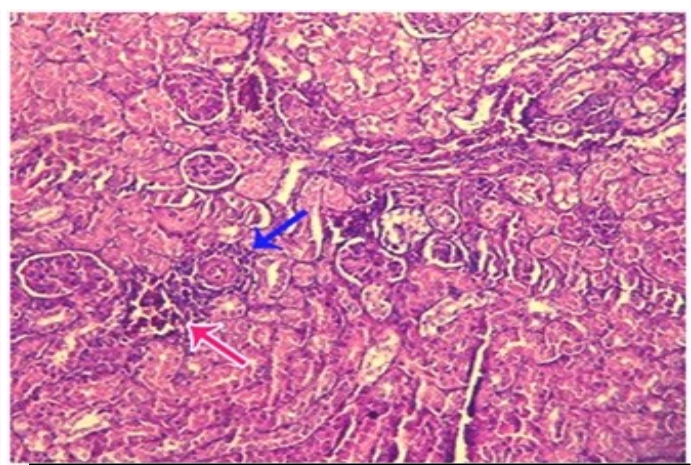

Figure (8) :Histopathological section of Kidney in mice injected with $0.1 \mathrm{ml}$ of purified toxin at concentration $2 \mu \mathrm{g} / \mathrm{ml}$ showed necrotic area infiltered with inflamatory cells(red arrow)also presence of inflamatory cells cuffing of the blood vessels ( blue arrow).(x100).H \& E.

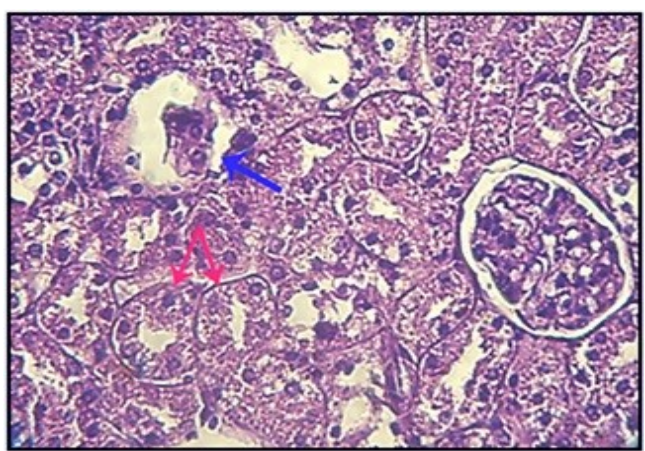

Figure (9) : Histopathological section of Kidney in mice injected with $0.1 \mathrm{ml}$ of purified toxin at concentration $4 \mu \mathrm{g} / \mathrm{ml}$ showed atrophy of glomerular tafts(blue arrow) and enlargement of epithelial lining urinary tubules lead to stenosis of lumen(red arrow).(x400).H \& E.

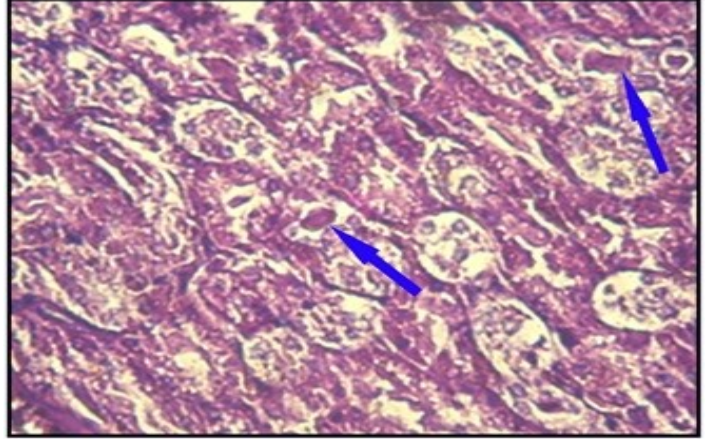

Figure (10) :Histopathological section of Kidney in mice injected with $0.1 \mathrm{ml}$ of purified toxin at concentration $3 \mu \mathrm{g} / \mathrm{ml}$ showed destruction and slouphing of epithelial lining urinary tubules with formation of hyaline cast blue arrow). (x200) .H \& E 


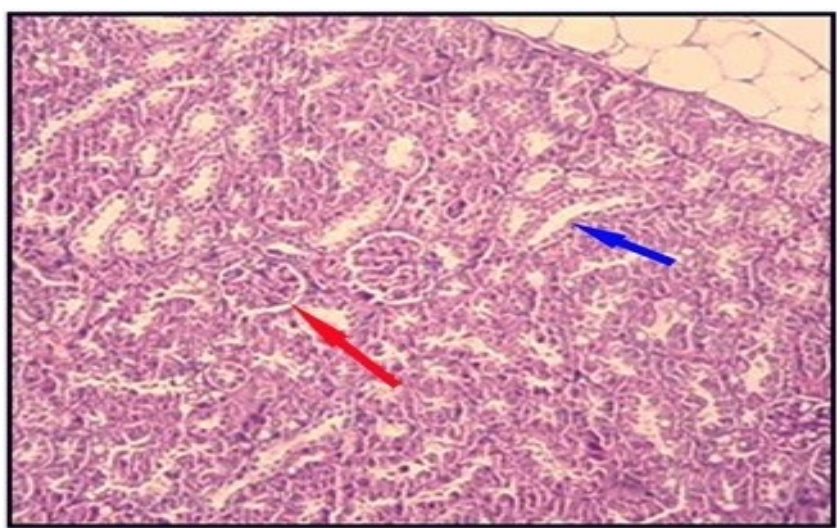

Figure (11): HistopathologicalsectionofKidney in control group injected with $0.1 \mathrm{ml}$ of Tris-oH showed normal tissue section consist of glomeruli (red arrow) and urinary tubules ( blue arrow) . (x100).H \& E. 